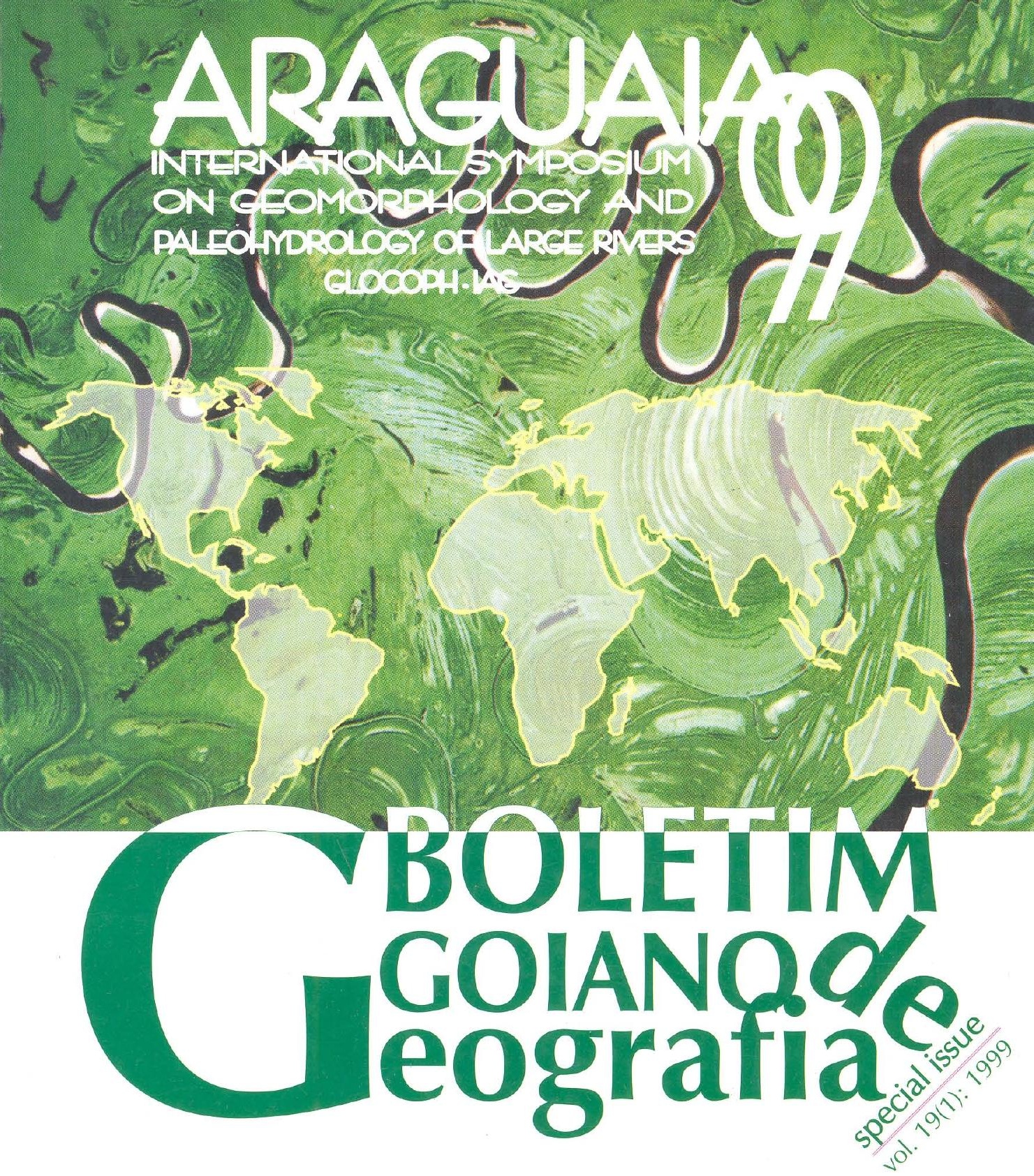

FEDERAL UNIVERSITY OF GOIÁS 'NSTITUTE OF SOCIAL \& ENVIRONMENTAL STUDIES - IESA

Seografia

dentais - IESA - US

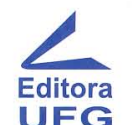




\section{AN INTRODUCTION TO LARGE RIVERS}

\section{Avijit Gupta}

School of Geography, University of Leeds, Leeds, UK

The International Association of Geomorphologists Working Group on Large Rivers was set up at the 1997 meeting of the IAG at Bologna. The objectives of the Working Group were as follows:

- to provide a forum for discussing the complexities of large rivers

- to arrange field visits to a number of large rivers

- to organise relevant and quality publications.

This meeting in Brazil on the Araguaia River is the first of a series of field trips planned by the Working Group. The next field trip will be on the Yangtze later this year. Subsequent field trips being planned include meetings on the Mekong, the Cooper-Diamantina, and the Fraser. These field conferences are designed to provide the participants with an opportunity to familiarise themselves with various rivers from different types of environment under guidance from geomorphologists who have already worked on such rivers. It is hoped that this experience will enhance research on a number of large rivers thereby providing us with a collection of useful case studies and models on their morphology and behaviour. Fluvial geomorphology and fluvial sedimentology so far are overwhelmingly dependent on case studies from smaller streams. This is to be expected, in part because of logistical difficulties in studying rivers and basins beyond a certain size, but it certainly leaves a lacuna in our understanding of the fluvial environment.

At the beginning of this venture we should recognise several earlier attempts. Potter (1978) discussed the significance and origin of large rivers. Meade (1996) published two lists (one for average suspended- 
sediment discharge and the other for average water discharge) for the major rivers of the world. The list included rivers which have been studied in detail and also those which have not. Information on the Mississippi is available but not on the Salween. Information is patchily available on a number of rivers on the list such as the Brahmaputra or the Zaire. Recent studies such as those on the Amazon or the Purari-Fly have ameliorated the situation to some extent but there is considerable room for extending our knowledge. The availability of water and sediment records does not necessarily coincide with a proper geomorphological account or with an elucidation of their geological history. Nearly half of the sediment reaching the coasts comes from the large rivers of Asia which rise in the Himalayas and the other mountains that came into existence due to the collision between the Indian and the Eurasian plates (Milliman and Meade, 1983). About 20 percent of the world's freshwater discharge is carried by the Amazon. It is therefore crucial to fill in the gaps in our knowledge regarding the geomorphology and sedimentology of large rivers.

A number of case studies on large rivers have started to appear recently as either journal articles (too many to list in an abstract) or part of recent anthologies of river studies (Warner, 1988; Tinkler and Wohl, 1998; Miller and Gupta, 1999). Such studies have highlighted a number of fluvial forms and river adjustments that have not been properly studied earlier and not included in standard textbooks. We know now of rivers that are partly on bedrock and partly on alluvium, rivers which flow from one climatic zone to another and have to undergo form adjustments, tropical rivers affected by high-magnitude floods. It is perhaps reasonable to suggest that neither the existing facies models nor computational models fit such rivers.

We need to study large rivers of the world for many reasons: because they are fascinating, because we do not know much about them, because their form and behaviour at times come into conflict with material presented in standard textbooks, because their role in fluvial sedimentology is still somewhat obscure, because they contribute a very 
large amount of water and sediment to the coastal areas, and because such rivers are often altered by engineering structures and changes in basin land use with large-scale negative environmental effects. This meeting is a step in the right direction and hopefully the future programme of the Working Group will contribute at least a little bit towards making us familiar to the form and behaviour of large rivers.

\section{References}

Meade, R.H. (1996) River-sediment inputs to major deltas, in Sea-Level Rise and Coastal Subsidence: Causes, Consequences, and Strategies (J.D. Milliman and B.U. Haq, Eds.), Kluwer Academic Publishers, Dordrecht, 63-85.

Miller, A.J. and Gupta, A., Eds. (1999) Varieties of Fluvial Form, John Wiley and Sons, Chichester.

Milliman J.D. and Meade, R.H. (1983) World-wide delivery of river sediment to the oceans, Journal of Geology, 91, 1-21.

Potter, P.E. (1978) Significance and origin of big rivers, Journal of Geology, 86, 13-33.

Tinkler, K.J. and Wohl, E.E., Eds. (1998) Rivers over Rock: Fluvial Processes in Bedrock Channels, Geophysical Monograph 107, American Geophysical Union, Washington, D.C.

Warner, R.F., Ed. (1988) Fluvial Geomorphology of Australia, Academic Press, Sydney. 